\title{
Three Complete Mitochondrial Genomes of Orestes guangxiensis, Peruphasma schultei, and Phryganistria guangxiensis (Insecta: Phasmatodea) and Their Phylogeny
}

\author{
Ke-Ke Xu ${ }^{1}$, Qing-Ping Chen ${ }^{1}$, Sam Pedro Galilee Ayivi ${ }^{1}{ }^{1}$, Jia-Yin Guan ${ }^{1}$, Kenneth B. Storey ${ }^{2}$, Dan-Na Yu ${ }^{1,3}$ and \\ Jia-Yong Zhang 1,3,*iD \\ 1 College of Chemistry and Life Science, Zhejiang Normal University, Jinhua 321004, China; \\ xkk20190815@163.com (K.-K.X.); 15157932450@163.com (Q.-P.C.); paydrov17@gmail.com (S.P.G.A.); \\ a1345413239@163.com (J.-Y.G.); ydn@zjnu.cn (D.-N.Y.) \\ 2 Department of Biology, Carleton University, Ottawa, ON K1S 5B6, Canada; KennethStorey@cunet.carleton.ca \\ 3 Key Lab of Wildlife Biotechnology, Conservation and Utilization of Zhejiang Province, Zhejiang Normal \\ University, Jinhua 321004, China \\ * Correspondence: zhang3599533@163.com or zhangjiayong@zjnu.cn
}

check for updates

Citation: Xu, K.-K.; Chen, Q.-P.; Ayivi, S.P.G.; Guan, J.-Y.; Storey, K.B.; Yu, D.-N.; Zhang, J.-Y. Three Complete Mitochondrial Genomes of Orestes guangxiensis, Peruphasma schultei, and Phryganistria guangxiensis (Insecta: Phasmatodea) and Their Phylogeny. Insects 2021, 12, 779. https://doi.org/ $10.3390 /$ insects 12090779

Academic Editor: Marcé D. Lorenzen

Received: 30 July 2021

Accepted: 28 August 2021

Published: 31 August 2021

Publisher's Note: MDPI stays neutral with regard to jurisdictional claims in published maps and institutional affiliations.

Copyright: (c) 2021 by the authors. Licensee MDPI, Basel, Switzerland. This article is an open access article distributed under the terms and conditions of the Creative Commons Attribution (CC BY) license (https:// creativecommons.org/licenses/by/ $4.0 /)$.
Simple Summary: Twenty-seven complete mitochondrial genomes of Phasmatodea have been published in the NCBI. To shed light on the intra-ordinal and inter-ordinal relationships among Phasmatodea, more mitochondrial genomes of stick insects are used to explore mitogenome structures and clarify the disputes regarding the phylogenetic relationships among Phasmatodea. We sequence and annotate the first acquired complete mitochondrial genome from the family Pseudophasmatidae (Peruphasma schultei), the first reported mitochondrial genome from the genus Phryganistria of Phasmatidae (P. guangxiensis), and the complete mitochondrial genome of Orestes guangxiensis belonging to the family Heteropterygidae. We analyze the gene composition and the structure of the three mitochondrial genomes. We recover the monophyly of Phasmatodea and show the sister-group relationship between Phasmatodea and Mantophasmatodea after removal of the Embioptera and Zoraptera species. We recover the monophyly of Heteropterygidae and the paraphyly of Diapheromeridae, Phasmatidae, Lonchodidae, Lonchodinae, and Clitumninae.

Abstract: Insects of the order Phasmatodea are mainly distributed in the tropics and subtropics and are best known for their remarkable camouflage as plants. In this study, we sequenced three complete mitochondrial genomes from three different families: Orestes guangxiensis, Peruphasma schultei, and Phryganistria guangxiensis. The lengths of the three mitochondrial genomes were $15,896 \mathrm{bp}, 16,869 \mathrm{bp}$, and $17,005 \mathrm{bp}$, respectively, and the gene composition and structure of the three stick insects were identical to those of the most recent common ancestor of insects. The phylogenetic relationships among stick insects have been chaotic for a long time. In order to discuss the intra- and inter-ordinal relationship of Phasmatodea, we used the 13 protein-coding genes (PCGs) of 85 species for maximum likelihood (ML) and Bayesian inference (BI) analyses. Results showed that the internal topological structure of Phasmatodea had a few differences in both ML and BI trees and long-branch attraction (LBA) appeared between Embioptera and Zoraptera, which led to a non-monophyletic Phasmatodea. Consequently, after removal of the Embioptera and Zoraptera species, we re-performed ML and BI analyses with the remaining 81 species, which showed identical topology except for the position of Tectarchus ovobessus (Phasmatodea). We recovered the monophyly of Phasmatodea and the sistergroup relationship between Phasmatodea and Mantophasmatodea. Our analyses also recovered the monophyly of Heteropterygidae and the paraphyly of Diapheromeridae, Phasmatidae, Lonchodidae, Lonchodinae, and Clitumninae. In this study, Peruphasma schultei (Pseudophasmatidae), Phraortes sp. YW-2014 (Lonchodidae), and species of Diapheromeridae clustered into the clade of Phasmatidae. Within Heteropterygidae, O. guangxiensis was the sister clade to O. mouhotii belonging to Dataminae, and the relationship of (Heteropteryginae + (Dataminae + Obriminae) $)$ was recovered. 
Keywords: stick insects; phylogenetic relationships; protein-coding gene; monophyly

\section{Introduction}

Stick and leaf insects (Phasmatodea) belong to an order of polyneopteran insects, which includes over 3000 recognized species subdivided into approximately 500 genera, distributed across major landmasses [1]. Phasmatodea are the longest insects among extant species, mainly distributed in tropical and subtropical regions, with a few species in temperate regions [2]. Phasmatodea are herbivorous insects and have a strong ability to masquerade as bark, leaves, and twigs, which provide them with camouflage [3-5]. Consequently, it is difficult to explore the phylogenetic relationship of Phasmatodea by the degree of convergence of morphology [6].

The phylogenetic relationship of Phasmatodea within Polyneoptera has been under debate. Polyneoptera includes ten insect orders of Blattodea, Dermaptera, Embioptera, Grylloblattodea, Mantodea, Mantophasmatodea, Orthoptera, Phasmatodea, Plecoptera, and Zoraptera. Both morphological and molecular data highly support Embioptera as the sister group of Phasmatodea [7-12]. Some studies showed that Phasmatodea formed a sister group to the Mantophasmatodea [13-16], whereas other analyses alternately supported a closer relationship between Phasmatodea and Orthoptera [8,17-19]. Moreover, recent research based on mitochondrial genome data supported the idea that Phasmatodea had a close relationship with Embioptera and Zoraptera [20-22].

The high-level phylogenetic relationships of Phasmatodea are currently not sufficiently clear [23,24]. Several authors have suggested that Phasmatodea should be divided into two suborders: Timematodea and Euphasmatodea (Verophasmatodea) $[1,5,25,26]$. The Euphasmatodea includes thirteen families: Aschiphasmatidae, Damasippoididae, Prisopodidae, Anisacanthidae, Bacillidae, Heteropterygidae, Phylliidae, Agathemeridae, Heteronemiidae, Pseudophasmatidae, Diapheromeridae, Lonchodidae, and Phasmatidae [2]. However, the wingless Nearctic walking-stick, Timema of family Timematidae, is the only genus within the one family in Timematodea [27]. Neverthless, Simon et al. demonstrated a basal dichotomy of Aschiphasmatodea and the Neophasmatodea in Euphasmatodea [28]. This result was also supported by Tihelka et al. [29]. The monophyly of Phasmatodea remains in dispute because of the phylogenetic position of genus Timema. Most studies based on morphology, transcriptome, and mitochondrial genome data have shown that the monophyly of Phasmatodea can be confirmed, and Timema is recognized as the sister group to all remaining phasmids [28,30-33]. Nevertheless, data on mitochondrial genomes considered that Timema did not belong to the Euphasmatodea, but grouped with other orders (e.g., Orthoptera and Embioptera) [6,34]. This result coincided with the study about the morphology of Timema species in egg that indicated that Timema was a separate lineage [35]. Based on 16S, 12S RNA genes, and protein codon genes, Song et al. [22] constructed nine phylogenetic trees, and eight of these failed to recover the monophyly of Phasmatodea because the clade of Embioptera and Zoraptera that existed in long-branch attraction (LBA) was a sister group to Euphasmatodea, whereas only one phylogenetic tree supported the monophyly of Phasmatodea, as found in Song et al. [36]. In many phylogenetic analyses, especially those based on mitochondrial genomes, biases associated with LBA have been found [37].

Insect mitochondrial genomes normally have 37 genes (thirteen protein-coding genes, two ribosomal RNAs, and 22 transfer RNA genes) and a control region (CR) and are usually a 14-20 kb double-stranded circular molecule [38]. The mitochondrial genome has been widely used for phylogenetic analyses due to its simple and stable gene organization, lack of genetic recombination, and fast evolution rate, etc. [21,39-41]. Many researchers have discussed the phylogenetic relationships among insect orders using mitochondrial genomes, such as Diptera [42], Orthoptera [43], Hymenoptera [44], and Coleoptera [45]. 
Hence, the mitochondrial genome of stick insects was used for phylogenetic analysis in this study.

At present, 27 complete mitochondrial genomes of Phasmatodea have been published in the NCBI. To shed light on the intra-ordinal and inter-ordinal relationships among Phasmatodea, we sequenced and annotated three complete mitochondrial genomes from Orestes guangxiensis (Bi \& Li, 1994) (Heteropterygidae), Phryganistria guangxiensis Chen \& He, 2008 (Phasmatidae), and Peruphasma schultei Conle \& Hennemann, 2005 (Pseudophasmatidae). This included the first acquired complete mitochondrial genome from the Pseudophasmatidae and the first reported mitochondrial genome of Phryganistria (Phasmatidae). Moreover, we analyzed the gene composition and the structure of the three mitochondrial genomes.

\section{Materials and Methods}

\subsection{Sampling Collection and DNA Extraction}

Orestes guangxiensis and Ph. guangxiensis were collected from Jinxiu, Guangxi province, China, whereas Pe. schultei was retrieved from an insect pet market in China, the source area being Northern Peru. According to their morphological characters, these specimens were identified by JY Zhang and stored at $-40^{\circ} \mathrm{C}$ in the Zhang laboratory, College of Life Sciences and Chemistry, Zhejiang Normal University, China. Total DNA was extracted from a piece of foreleg muscle using a Universal Genomic DNA Kit (Co Win Biosciences Company, Beijing, China).

\subsection{PCR Amplification and Sequencing}

The DNA from each of the three species was amplified using eight pairs of universal primers, as described in Zhang et al. [46], but there were still some vacancies. We then used Primer Premier 5.0 to design species-specific primers based on known sequences from universal primers [47] (Table S1) and used normal PCR (product length $<3000 \mathrm{bp}$ ) as well as long PCR (product length $>3000 \mathrm{bp}$ ) methods for amplification [46]. Takara Taq polymerase and Takara LATaq DNA polymerase were used, respectively (Takara, Dalian, China), in a $50 \mu \mathrm{L}$ reaction volume. Reaction systems and cycling conditions for normal PCR and long PCR were as described in Zhang et al. [46]. All PCR products were sequenced in both directions using the primer-walking method and ABI3730XL by Sangon Biotech Company (Shanghai, China).

\subsection{Mitochondrial Genome Annotation and Sequence Analyses}

The fragments obtained by Sanger dideoxy sequencing were assembled with DNASTAR Package v.7.1 [48]. The tRNA genes were identified using the MITOS web server (http:/ / mitos.bioinf.uni-leipzig.de/index.py (accessed on 15 July 2021)) [49]. Based on the homologous sequences of mitochondrial genomes from other stick insect species, we used Clustal X [50] to determine the two rRNA genes (12S and 16S rRNA). The remaining 13 protein-coding genes were analyzed using Mega 7.0 [51] to translate amino acids using the invertebrate mitochondrial genetic code and find open reading frames [52]. The AT content, codon usage, and relative synonymous codon usage (RSCU) of protein-coding genes were calculated by PhyloSuite 1.2.2 [53]. GC and AT skews were calculated according to the formula: AT skew $=(A-T) /(A+T), G C$ skew $=(G-C) /(G+C)[54]$.

\subsection{Phylogenetic Analyses}

To illuminate the phylogenetic relationships of Phasmatodea, we first performed maximum likelihood (ML) and Bayesian inference (BI) analyses based on data from 85 species, including the three newly determined sequences, sixty-five previously sequenced mitochondrial genomes, and 13 PCGs of seventeen species of Phasmatodea assembled from transcriptome data [14,33,34,36,55-77] (Table 1, Table 2 and Table S2). Long-branch attraction between Embioptera and Zoraptera appeared in both ML and BI phylogenetic trees and affected the stability of the topology. This phenomenon probably occurred because of phylogenetic artifacts generated by the mitochondrial genome [78]. For LBA, the following 
measures are recommended: increasing samples [79]; removing long-branch groups [80]; or removing sites with rapid evolutionary rates [81]. Adding sequences was not feasible because all current mitochondrial genome sequences of Embioptera and Zoraptera were used in this study. Then, we attempted to remove sites with fast evolutionary rates, but nevertheless, the results were not very reliable. Therefore, we reconstructed BI and ML phylogenetic trees with 13 concatenated PCG sequences of 81 species after removing representative species of Embioptera and Zoraptera. Three species of Archaeognatha, Nesomachilis australica, Pedetontus silvestrii, and Trigoniophthalmus alternatus were used as outgroups (Table 2). We aligned each of the 13 protein-coding genes using Clustal W in the program Mega 7.0 [51] and used the program Gblock $0.91 \mathrm{~b}$ to identify conserved regions [82]. The resulting alignments were concatenated with Geneious 8.1.6 [83]. Because the third codon positions had saturated by DAMBE 4.2.13 [84], we used the Bayesian inference (BI) and maximum likelihood (ML) methods with the first and second codon datasets to analyze the phylogenetic relationships. ML analysis was implemented by IQ-TREE v.2.1.2 with the best model GTR + I + G that was acquired by ModelFinder [85,86]. BI analysis was carried out by MrBayes 3.2 with GTR + I + G [87] and was set for 10 million generations with sampling every 1000 generations, and the first $25 \%$ of generations were discarded as burn-in.

Table 1. Species of Phasmatodea used to construct the phylogenetic relationships along with GenBank accession numbers.

\begin{tabular}{|c|c|c|c|c|c|}
\hline Family & Subfamily & Species & Length & Accession no. & Reference \\
\hline \multirow[t]{3}{*}{ Phylliidae } & \multirow[t]{3}{*}{ Phylliinae } & Cryptophyllium tibetense & $18,248 \mathrm{bp}$ & KX091862 & $\begin{array}{l}\text { Directly Submitted } \\
\text { [88] }\end{array}$ \\
\hline & & Pulchriphyllium giganteum & $13,980 \mathrm{bp}$ & AB477461 & {$[6,88]$} \\
\hline & & Cryptophyllium westwoodii & $17,222 \mathrm{bp}$ & MW229063 & {$[88,89]$} \\
\hline Timematidae & Timematinae & Timema californicum & $14,387 \mathrm{bp}$ & DQ241799 & [14] \\
\hline \multirow{2}{*}{ Bacillidae } & \multirow{2}{*}{ Bacillinae } & Bacillus rossius & $14,152 \mathrm{bp}$ & GŨ001956 & [15] \\
\hline & & Bacillus atticus & $14,141 \mathrm{bp}$ & GU001955 & {$[15]$} \\
\hline \multirow{3}{*}{ Heteropterygidae } & \multirow{2}{*}{ Dataminae } & Orestes mouhotii & $16,223 \mathrm{bp}$ & AB477462 & [6] \\
\hline & & Orestes guangxiensis & $16,869 \mathrm{bp}$ & MW450873 & This study \\
\hline & Heteropteryginae & Heteropteryx dilatata & $16,618 \mathrm{bp}$ & AB477468 & [6] \\
\hline \multirow[t]{9}{*}{ Phasmatidae } & Megacraniinae & Megacrania alpheus & $17,124 \mathrm{bp}$ & AB477471 & [6] \\
\hline & Extatosomatinae & Extatosoma tiaratum & $16,537 \mathrm{bp}$ & AB642680 & [6] \\
\hline & \multirow[t]{6}{*}{ Clitumninae } & Entoria nuda & $16,910 \mathrm{bp}$ & AB477459 & [6] \\
\hline & & Phobaeticus serratipes & $16,182 \mathrm{bp}$ & AB477467 & [6] \\
\hline & & Ramulus hainanense & $15,590 \mathrm{bp}$ & FJ156750 & Directly Submitted \\
\hline & & Ramulus mikado & $16,633 \mathrm{bp}$ & AB477463 & [6] \\
\hline & & Phryganistria guangxiensis & $17,005 \mathrm{bp}$ & MW450875 & This study \\
\hline & & Pharnaciini sp. NS-2020 & $15,192 \mathrm{bp}$ & MT025193 & [22] \\
\hline & Phasmatinae & Dryococelus australis & $16,604 \mathrm{bp}$ & AP018522 & {$[90]$} \\
\hline \multirow[t]{11}{*}{ Lonchodidae } & \multirow[t]{6}{*}{ Lonchodinae } & Phraortes elongatus & $16,456 \mathrm{bp}$ & AB477460 & [6] \\
\hline & & Megalophasma granulatum & $15,275 \mathrm{bp}$ & KY124331 & {$[91]$} \\
\hline & & $\begin{array}{l}\text { Phraortes sp. Miyako } \\
\text { Island }\end{array}$ & $14,913 \mathrm{bp}$ & AB477465 & {$[6]$} \\
\hline & & $\begin{array}{l}\text { Phraortes sp. Iriomote } \\
\text { Island }\end{array}$ & $16,867 \mathrm{bp}$ & AB477464 & [6] \\
\hline & & Phraortes sp. 1 NS-2020 & $14,207 \mathrm{bp}$ & МT025191 & [22] \\
\hline & & Eurycantha calcarata & $16,280 \mathrm{bp}$ & MW915467 & Directly Submitted \\
\hline & \multirow[t]{5}{*}{ Necrosciinae } & Micadina phluctainoides & $16,507 \mathrm{bp}$ & AB477466 & [6] \\
\hline & & Sipyloidea sipylus & $17,001 \mathrm{bp}$ & AB477470 & {$[6]$} \\
\hline & & Calvisia medogensis & $16,107 \mathrm{bp}$ & KY124330 & [91] \\
\hline & & Neohirasea japonica & $15,305 \mathrm{bp}$ & AB477469 & [6] \\
\hline & & Micadina brachyptera & $15,879 \mathrm{bp}$ & MT025192 & [22] \\
\hline Pseudophasmatidae & Pseudophasmatinae & Peruphasma schultei & $15,896 \mathrm{bp}$ & MW450874 & This study \\
\hline
\end{tabular}


Table 2. Species of other insects (excluding species of Phasmatodea) used to construct the phylogenetic relationships along with GenBank accession numbers.

\begin{tabular}{|c|c|c|c|}
\hline Order & Species & GenBank No. & References \\
\hline \multirow[t]{3}{*}{ Archaeognatha } & Nesomachilis australica & AY793551 & [55] \\
\hline & Pedetontus silvestrii & EU621793 & [56] \\
\hline & Trigoniophthalmus alternatus & EU016193 & [57] \\
\hline \multirow[t]{3}{*}{ Zygentoma } & Tricholepidion gertschi & AY191994 & [58] \\
\hline & Atelura formicaria & EU084035 & [59] \\
\hline & Thermobia domestica & AY639935 & [60] \\
\hline \multirow[t]{3}{*}{ Odonata } & Davidius lunatus & EU591677 & Directly Submitted \\
\hline & Somatochlora hineana & MG594801 & Directly Submitted \\
\hline & Brachythemis contaminata & KM658172 & {$[61]$} \\
\hline \multirow[t]{8}{*}{ Ephemeroptera } & Siphluriscus chinensis & HQ875717 & {$[62]$} \\
\hline & Isonychia ignota & HM143892 & Directly Submitted \\
\hline & Paegniodes cupulatus & HM004123 & Directly Submitted \\
\hline & Serratella zapekinae & MT274130 & [63] \\
\hline & Parafronurus youi & EU349015 & [64] \\
\hline & Caenis sp. JYZ-2018 & MG910499 & [65] \\
\hline & Epeorus sp. JZ-2014 & KJ493406 & Directly Submitted \\
\hline & Epeorus sp. MT-2014 & KM244708 & [66] \\
\hline \multirow{3}{*}{ Plecoptera } & Pteronarcys princeps & AY687866 & [67] \\
\hline & Acroneuria hainana & KM199685 & [68] \\
\hline & Isoperla bilineata & MF716959 & [69] \\
\hline \multirow[t]{3}{*}{ Orthoptera } & Locusta migratoria & X80245 & [77] \\
\hline & Gastrimargus marmoratus & EU513373 & [70] \\
\hline & Oedaleus decorus asiaticus & EU513374 & [70] \\
\hline Grylloblattodea & Grylloblatta sculleni & DQ241796 & {$[14]$} \\
\hline Mantophasmatodea & Sclerophasma paresisensis & DQ241798 & [14] \\
\hline \multirow[t]{3}{*}{ Mantodea } & Paratoxodera polyacantha & MG049920 & Directly Submitted \\
\hline & Mantis religiosa & MN356097 & [71] \\
\hline & Pliacanthopus bimaculatus & MT679725 & [72] \\
\hline \multirow[t]{3}{*}{ Embioptera } & Aposthonia japonica & AB639034 & [34] \\
\hline & Aposthonia borneensis & KX091848 & Directly Submitted \\
\hline & Eosembia sp. FS-2017 & KX091852 & Directly Submitted \\
\hline \multirow[t]{3}{*}{ Blattodea } & Cryptotermes declivis & MK599465 & [73] \\
\hline & Coptotermes formosanus & AB626147 & [74] \\
\hline & Macrotermes subhyalinus & JX144937 & [75] \\
\hline Zoraptera & Zorotypus medoensis & JQ910991 & Directly Submitted \\
\hline \multirow{3}{*}{ Dermaptera } & Challia fletcheri & JN651407 & [76] \\
\hline & Euborellia arcanum & KX673196 & [36] \\
\hline & Eudohrnia metallica & KX091853 & [36] \\
\hline
\end{tabular}

\section{Results and Discussion}

\subsection{Mitochondrial Genome Organization and Composition}

The lengths of the three complete mitochondrial genomes of O. guangxiensis, Pe. schultei, and Ph. guangxiensis were 16,869 bp, 15,896 bp, and 17,005 bp, respectively (Figure 1). All three genomes were deposited in GenBank, with accession numbers MW450873, MW450874, and MW450875, respectively. Mitochondrial genomes of the three species had the same genes and gene order as those of other published stick insects, which have 37 genes, including 13 PCGs, 22 tRNA genes, and two rRNA genes. Currently, the gene arrangement of published stick insects is similar to the assumed common ancestor of insects, except for Ramulus hainanense (CR-trnM-trnQ-trnI-CR-trnI-trnQ-trnM) and Megalophasma granulatum (trnR-trnA) [6,14,15,22,30,89-91]. According to the previously published complete mitochondrial genomes of stick and leaf insects, we found that the differing lengths of the Phasmatodea genomes $(15,590-18,248 \mathrm{bp})$ were caused mainly by the size of the $\mathrm{A}+\mathrm{T}$-rich region, gene overlaps, and different intergenic nucleotides (IGNs). The sequence length of Pe. schultei (15,896 bp), with a short A + T-rich region ( $<1500 \mathrm{bp})$, was the shortest after that of $R$. hainanense $(15,590 \mathrm{bp})$. The three species have short intergenic regions 
ranging from 1 to $18 \mathrm{bp}$. The whole mitochondrial genome of Ph. guangxiensis, which contained additional IGNs (136 bp), was longer than that of O. guangxiensis (Tables S3-S5). The nucleotide composition of the O. guangxiensis, Pe. schultei, and Ph. guangxiensis mitochondrial genomes had a high A + T bias of $75.6 \%, 76.6 \%$, and $76.8 \%$, respectively. All three species showed a positive AT skew and negative GC skew (Table 3). The content of A was more than $T$, and the content of $C$ was higher than $G$, which also occurred in the sequences of previously studied stick insects (Table S6) $[6,14,15,22,30,89-91]$.
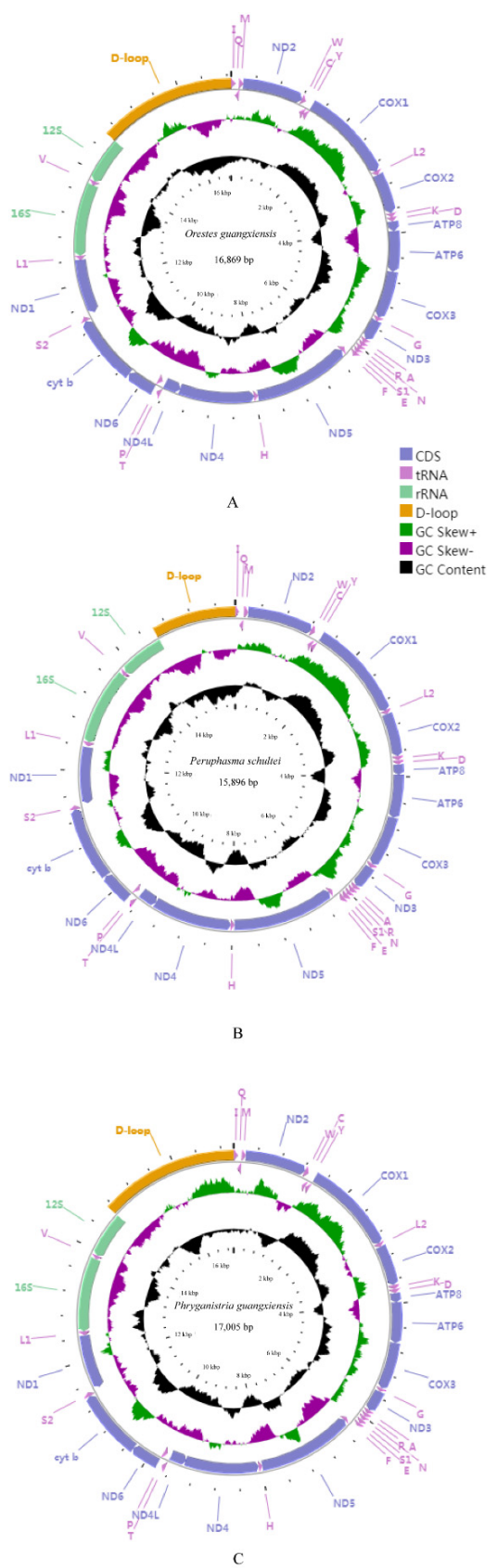

Figure 1. Mitochondrial genome maps of O. guangxiensis (A), Pe. schultei (B), and Ph. guangxiensis (C). The first circle shows the gene map (PCGs, rRNAs, tRNAs, and the AT-rich region). The genes shown outside the map are coded on the majority strand (J-strand), whereas the genes inside the map are coded on the minority strand (N-strand). The second circle shows the GC skew and the third shows the GC content. GC content and GC skew are plotted as the deviation from the average value of the entire sequence. 
Table 3. Base composition of the mitochondrial genomes of the three species.

\begin{tabular}{|c|c|c|c|c|c|c|c|c|c|c|c|c|c|}
\hline \multirow{2}{*}{\multicolumn{2}{|c|}{ Region }} & \multicolumn{4}{|c|}{ O. guangxiensis } & \multicolumn{4}{|c|}{ Pe. schultei } & \multicolumn{4}{|c|}{ Ph. guangxiensis } \\
\hline & & \multirow{2}{*}{$\begin{array}{c}\text { Length(bp) } \\
16,869\end{array}$} & \multirow{2}{*}{$\begin{array}{c}\begin{array}{c}A+T \\
(\%)\end{array} \\
75.6\end{array}$} & $\begin{array}{c}\text { AT } \\
\text { Skew }\end{array}$ & $\begin{array}{c}\text { GC } \\
\text { Skew }\end{array}$ & Length(bp) & $\begin{array}{c}A+T \\
(\%)\end{array}$ & $\begin{array}{c}\text { AT } \\
\text { Skew }\end{array}$ & $\begin{array}{c}\text { GC } \\
\text { Skew }\end{array}$ & Length(bp) & $\begin{array}{c}A+T \\
(\%)\end{array}$ & $\begin{array}{c}\text { AT } \\
\text { Skew }\end{array}$ & $\begin{array}{c}\text { GC } \\
\text { Skew }\end{array}$ \\
\hline mito & & & & 0.19 & -0.22 & 15,896 & 76.6 & 0.16 & -0.19 & 17,005 & 76.8 & 0.16 & -0.19 \\
\hline PCGs & $\begin{array}{l}\mathrm{J} \\
\mathrm{N}\end{array}$ & 11,112 & 74.2 & $\begin{array}{l}0.06 \\
-0.38\end{array}$ & $\begin{array}{l}-0.16 \\
0.28\end{array}$ & 11,100 & 75.5 & $\begin{array}{l}0.03 \\
-0.35\end{array}$ & $\begin{array}{l}-0.12 \\
0.25\end{array}$ & 11,121 & 75.8 & $\begin{array}{l}0.06 \\
-0.37\end{array}$ & $\begin{array}{l}-0.14 \\
0.26\end{array}$ \\
\hline rRNAs & & 2079 & 78.3 & 0.25 & -0.32 & 2055 & 77.7 & 0.22 & -0.30 & 2124 & 77.9 & 0.20 & -0.30 \\
\hline$A+T-r$ & region & 2238 & 79.6 & 0.17 & -0.29 & 1294 & 82.5 & 0.13 & -0.37 & 2286 & 79.1 & 0.10 & -0.17 \\
\hline
\end{tabular}

\subsection{Protein-Coding Genes and Codon Usages}

The locations of the 13 PCGs within the three mitochondrial genomes were identical to those of most stick insects (Tables S3-S5). Four PCGs (ND1, ND4, ND4L, and ND5) were located in the minority strand (N-strand), whereas the remaining PCGs were coded on the majority strand (J-strand). The total lengths of the 13 protein-coding genes (PCGs) in O. guangxiensis, Pe. schultei, and Ph. guangxiensis were 11,112 bp, 11,100 bp, and 11,121 bp, respectively (Table 3). Among the three mitochondrial genomes, all PCG initiation codons used ATN (N represents A, G, C, or T), except for ND4L of Pe. schultei, which started with GTG. GTG as a start codon has also been found in ND4 of Megalophasma granulatum [91]. ATN is an accepted canonical initiation codon for insect mitochondrial genomes [92]. Of the stick insects that used ATN as an initiation codon, most used ATA, ATG, and ATT, with only a few using ATC $[6,14,15,22,30,89-91]$; only ATP8 (Pe. schultei) used the ATC start codon in this study. The typical termination codons (TAA/TAG) were found in most PCGs, except for some incomplete terminal codons, such as T used for COX2 (O. guangxiensis, Pe. schultei, and Ph. guangxiensis), ND1 (Ph. guangxiensis), ND3 (O. guangxiensis and Pe. schultei), ND4L (Pe. schultei), and ND5 (O. guangxiensis and Pe. schultei). Incomplete termination codons have also been found in other insects [65,93-96]. Incomplete stop codons play a significant role in polycistronic transcription cleavage and polyadenylation processes [97]. High A $+\mathrm{T}$ bias was also found in the PCGs of O. guangxiensis, Pe. schultei, and Ph. guangxiensis, which were $74.2 \%, 75.5 \%$, and $75.8 \%$, respectively. The PCGs of the majority strand displayed positive AT skews and negative GC skews, whereas the minority strand displayed negative AT skews and positive GC skews. The A skew (the content of A > T) and C skew (the content of $C>G$ ) of the minority strand was greater than on the majority strand (Table 3).

We calculated the relative synonymous codon usage (RSCU) of the three mitochondrial genomes (Figure 2, Table S7). The results showed that A or T nucleotides were used in high frequency in the third codon position compared to other nucleotides, and that A was used more often than T. The most frequent codons used were UUU (Phe), UUA (Leu), AUU (Ile), and AUA (Met) and were used >280 times in the PCGs of O.guangxiensis, Pe. schultei, and Ph. guangxiensis mitochondrial genomes. In contrast, codons with a third codon G or C were used very rarely ( $\leq 10)$, such as CUC (Leu), UGC (Cys), CGC (Arg), GCG (Ala) $(\leq 5)$, etc. This may be a kind of AT mutation bias that has an obvious influence on codon usage $[98,99]$.

\subsection{Ribosomal RNAs and Transfer RNAs}

The mitochondrial genomes of O. guangxiensis, Pe. schultei, and Ph. guangxiensis each had 22 tRNA genes, as in other Phasmatodea mitogenomes [6,14,15,22,30,89-91]. The total tRNA sizes of O. guangxiensis, Pe. schultei, and Ph. guangxiensis were $1463 \mathrm{bp}$, $1432 \mathrm{bp}$, and $1468 \mathrm{bp}$, respectively, with a high $\mathrm{A}+\mathrm{T}$ bias of $78.3 \%, 77.6 \%$, and $79.2 \%$. Among the 22 tRNA genes of the three species, most secondary structures of the tRNA genes can fold into the common cloverleaf model, except for trnS1 (O. guangxiensis), which lacks the dihydrouridine (DHC) arm, and $\operatorname{trnN}(O$. guangxiensis and Pe. schultei) and trnP (O. guangxiensis), which had lost the TYC loops (Figures S1-S3). A lack of DHC arms or TIC loops exists in other stick insects and various insects in general [62,91,100-102], and these have lower translational activity compared to the normal structures [103]. We 
also found a few mismatched pairs, such as unmatched A-A base pairs in trnS1 of the three stick species, A-G in trnW (O.guangxiensis and Pe. schultei), C-A in trnG (Ph. guangxiensis), $\mathrm{U}-\mathrm{U}$ in $\operatorname{trn} \mathrm{V}$ of the three stick insects, as well as trnA (O. guangxiensis and Pe. schultei), $\operatorname{trn} Y$ (Ph. guangxiensis), trnS2, and trnL1(Pe. schultei). Mismatched pairs may affect aminoacylation and translation [104].

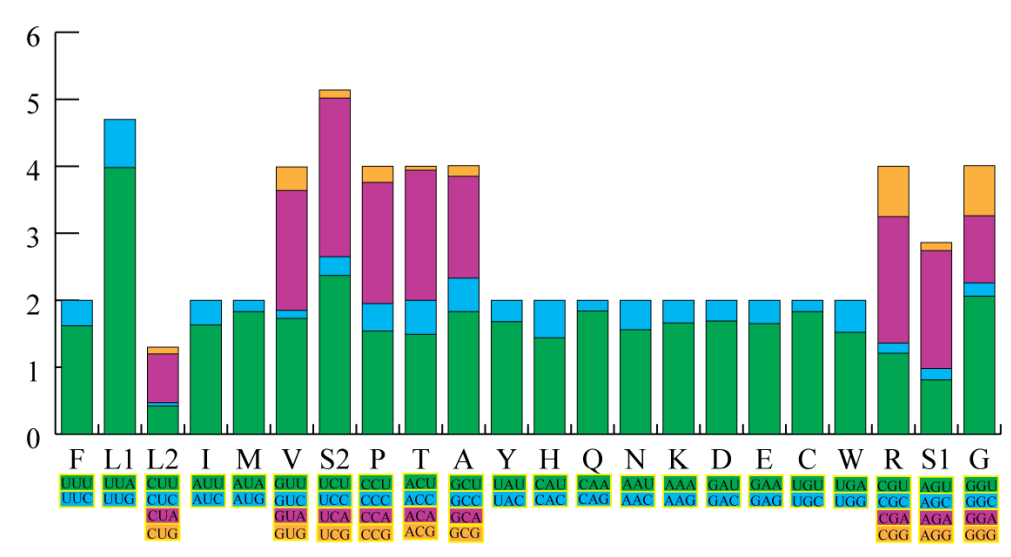

A

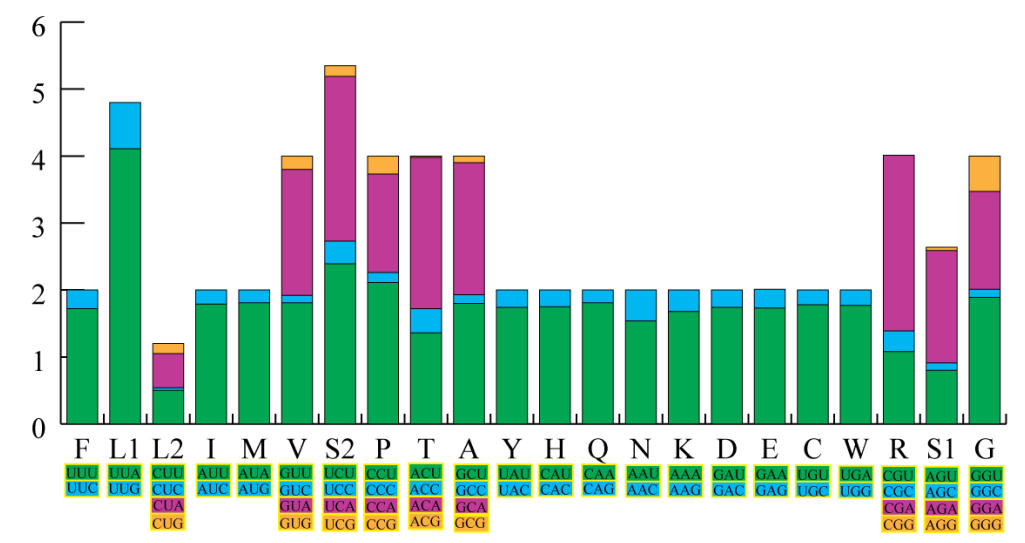

B

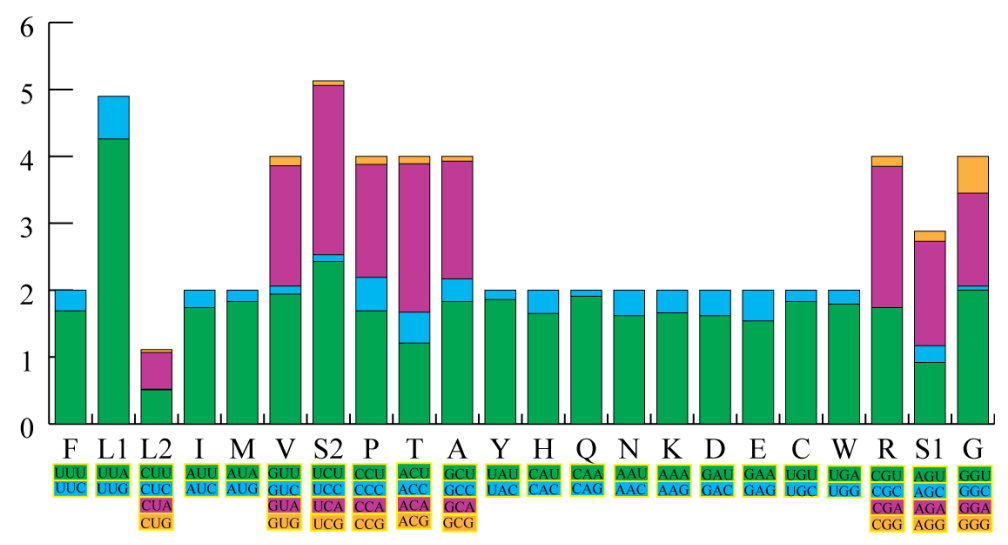

$\mathrm{C}$

Figure 2. The relative synonymous codon usage (RSCU) in three Phasmatodea mitochondrial genomes. The RSCU of the mitochondrial genome in O. guangxiensis (A), Pe. schultei (B), and Ph. guangxiensis (C). 
The mitochondrial genomes of these three stick insects, similar to other species in Phasmatodea, contained two rRNAs genes [6,15]. The 16S rRNA gene in O. guangxiensis, Pe. schultei, and Ph. guangxiensis was located between trnL1 and trnV, with a length of $1291 \mathrm{bp}, 1281 \mathrm{bp}$, and $1328 \mathrm{bp}$, respectively, whereas the 12S rRNA was located between trnV and the CR, with sizes of $788 \mathrm{bp}, 774 \mathrm{bp}$, and $796 \mathrm{bp}$, respectively. The AT content of the two rRNAs in O. guangxiensis (78.3\%), Pe. schultei (77.7\%), and Ph. guangxiensis (77.9\%) were each higher than the average AT content of the 13 PCGs (Table 3). We found that the AT skew values of the two rRNAs in O. guangxiensis, Pe. schultei, and Ph. guangxiensis were $0.25,0.22$, and 0.20 , respectively. Meanwhile, the GC skew was highly negative, with values around 0.3 (Table 3 ).

\subsection{A+T-Rich Region}

The large non-coding region of O. guangxiensis, Pe. schultei, and Ph. guangxiensis between trnI and 12S rRNA was an A + T-rich region with lengths of $2238 \mathrm{bp}, 1294 \mathrm{bp}$, and $2286 \mathrm{bp}$, respectively (Table 3). Compared with mitogenomes from other Phasmatodea, the length of the A + T-rich region in Pe. schultei was the shortest, except for Ramulus hainanense (774 bp) (FJ156750). According to the published complete Phasmatodea mitochondrial genomes, the longest $\mathrm{A}+\mathrm{T}$-rich region was found in Cryptophyllium tibetense (3701 bp) (KX091862). In the mitochondrial genomes of O. guangxiensis, Pe. schultei, and Ph. guangxiensis, the content of $\mathrm{A}+\mathrm{T}$ in the control regions was $79.6 \%, 82.5 \%$, and $79.1 \%$, respectively, which was higher than other partitions of mitochondrial genomes. The A + T-rich regions of the three species each showed positive AT skew values and negative GC skew values (Table 3 ). The $\mathrm{A}+\mathrm{T}$ region embodied the origin sites and essential regulatory elements needed for transcription and replication [105-107].

Repeat regions were observed in O. guangxiensis, Pe. schultei, and Ph. guangxiensis (Figure 3). The A + T-rich region of Ph. guangxiensis possessed seven copies of tandem repeats regions with a length of $106 \mathrm{bp}$, whereas the $\mathrm{A}+\mathrm{T}$-rich region of Pe. schultei contained six tandem repeat regions of a $32 \mathrm{bp}$ sequence. However, two repeats (172 bp) in O. guangxiensis were not tandem (Figure 3). Tandem repeats in the $\mathrm{A}+\mathrm{T}$ rich region have also been observed in many Phasmatodea species. In the research of Kômoto et al., the presence of tandem repeats in the $\mathrm{A}+\mathrm{T}$ region was also detected in eight Phasmatodea species, such as Entoria nuda (ten tandem repeats of a 128-129 bp sequence) and Ramulus mikado (two tandem repeats of a $149 \mathrm{bp}$ sequence and seven tandem repeats of $125 \mathrm{bp}$ ) [6]. Two identical copies of a $64 \mathrm{bp}$ tandem repeat were discovered in Ramulus hainanense (FJ15676), and Eurycantha calcarata included twenty-two tandem repeats of a $32 \mathrm{bp}$ fragment (MW915467). Twenty-two tandem repeats of a $21 \mathrm{bp}$ sequence were found in Cryptophyllium tibetense (KX091862), and Extatosoma tiaratum possessed three tandem repeats of a 128-129 bp fragment [30]. Phraortes sp. 1 NS-2020 contained two tandem repeats with lengths of $20 \mathrm{bp}$ [22]. The secondary structure of these repeat units was predicted by RNAalifold in 15 species [108-110]. We found that most of these tandem repeats in the $A+T$ region could form the stem-loop structure (Figure S4). Repeat regions of the mitochondrial A $+\mathrm{T}$ region also existed in other insects. The A + T-rich region of Theopompa sp.YN (Mantodea: Mantidae) contained three tandem repeats of a $200 \mathrm{bp}$ sequence [96]. Two tandem repeats of a $90 \mathrm{bp}$ sequence, three tandem repeats of a $100 \mathrm{bp}$ sequence, and six tandem repeats of a 50 bp sequence were observed in Serratella zapekinae (Ephemeroptera: Ephemerellidae) [63]. The cause of tandem repeats may be slipped-strand mispairing in mitochondrial genome replication [111].

\subsection{Intergenic and Overlap Regions}

The mitochondrial genomes of Phasmatodea, including the three stick insects in this study, were compact, with intergenic regions usually not exceeding 20 bp [6,14,15,22,30,89-91]. The mitochondrial genomes of O.guangxiensis, Pe. schultei, and Ph. guangxiensis contained 7, 5, and 12 intergenic regions with total lengths of $17 \mathrm{bp}, 41 \mathrm{bp}$, and $40 \mathrm{bp}$, respectively. We observed the longest intergenic spacer between ND1 and trnL1 and the second-longest 
between trnI and trnQ within the mitochondrial genomes of Pe. schultei, with lengths of $18 \mathrm{bp}$ and $13 \mathrm{bp}$, respectively. Overall, insertions between genes ranged from 1 to 8 residues in the three stick insects (Tables S3-S5).

Orestes guangxiensis

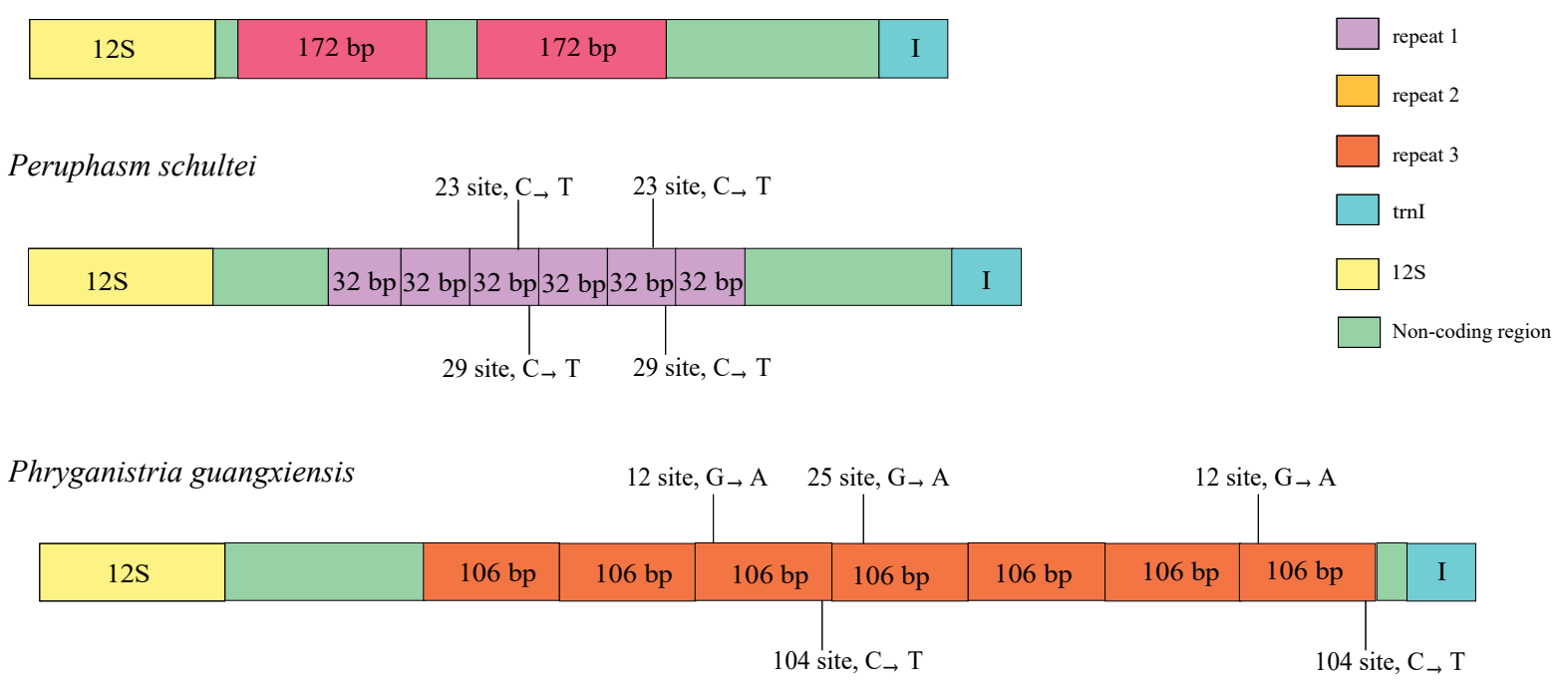

Figure 3. Organizations of the repeat regions in the control region of O. guangxiensis, Pe. schultei, and Ph. guangxiensis.

The mitochondrial genomes of O. guangxiensis, Pe. schultei, and Ph. guangxiensis had 14, 10, and 13 overlaps with a total length of $39 \mathrm{bp}, 28 \mathrm{bp}$, and $38 \mathrm{bp}$, respectively. Coincidentally, we observed that the three phasmatodean species shared four pairs of gene overlaps: trnW/trnC (8 bp), COX1/trnL2 (5 bp), ATP8/ATP6 (4 bp), and ATP6/COX3 (1 bp). The overlapping between ATP6 and COX3 was an A that also exists in all published Phasmatodea mitochondrial genomes [6,14,15,22,30,89-91]. An 8 bp (AAGYCTTA) overlap was also found between trnW and trnC that is present in all published sequences except Timema californicum and Dryococelus australis. Simultaneously, a pentanucleotide TCTAA consensus motif existed in the overlap regions situated between COX1 and trnL2 of a few other stick insects $[15,91]$.

\subsection{Phylogenetic Analyses}

When we analyzed the phylogenetic relationship using the 13PCGs of 85 species, including Embioptera and Zoraptera, the Bayesian tree was different from the maximum likelihood inference tree, mainly in the internal topological structure of Phasmatodea (Figures S5 and S6). We found that Phasmatodea was paraphyletic because the clade of Zoraptera and Embioptera clustered into the Phasmatodea, as also reported by Song et al. based on mitochondrial genome sequence data [22,36]. Zoraptera was the sister clade to Embioptera, caused by long-branch attraction, as found in Ma et al. [20].

After removal of the Embioptera and Zoraptera species, we re-performed ML and BI analyses with the remaining 81 species, which showed identical topology except for the position of Tectarchus ovobessus (Phasmatodea). Figure 4 shows that Odonata was the basal group of Pterygota, and Ephemeroptera was a sister clade to the Polyneoptera, as also reported by some other molecular and morphological studies $[62,112,113]$. The monophyly of Polyneoptera also was supported. We recovered the monophyly of Phasmatodea, and the sister-group relationship between Phasmatodea and Mantophasmatodea was supported by current phylogenetic analyses after removing Zoraptera and Embioptera. Phasmatodea was divided into two branches: Timematodea and Euphasmatodea (Figure 4). 

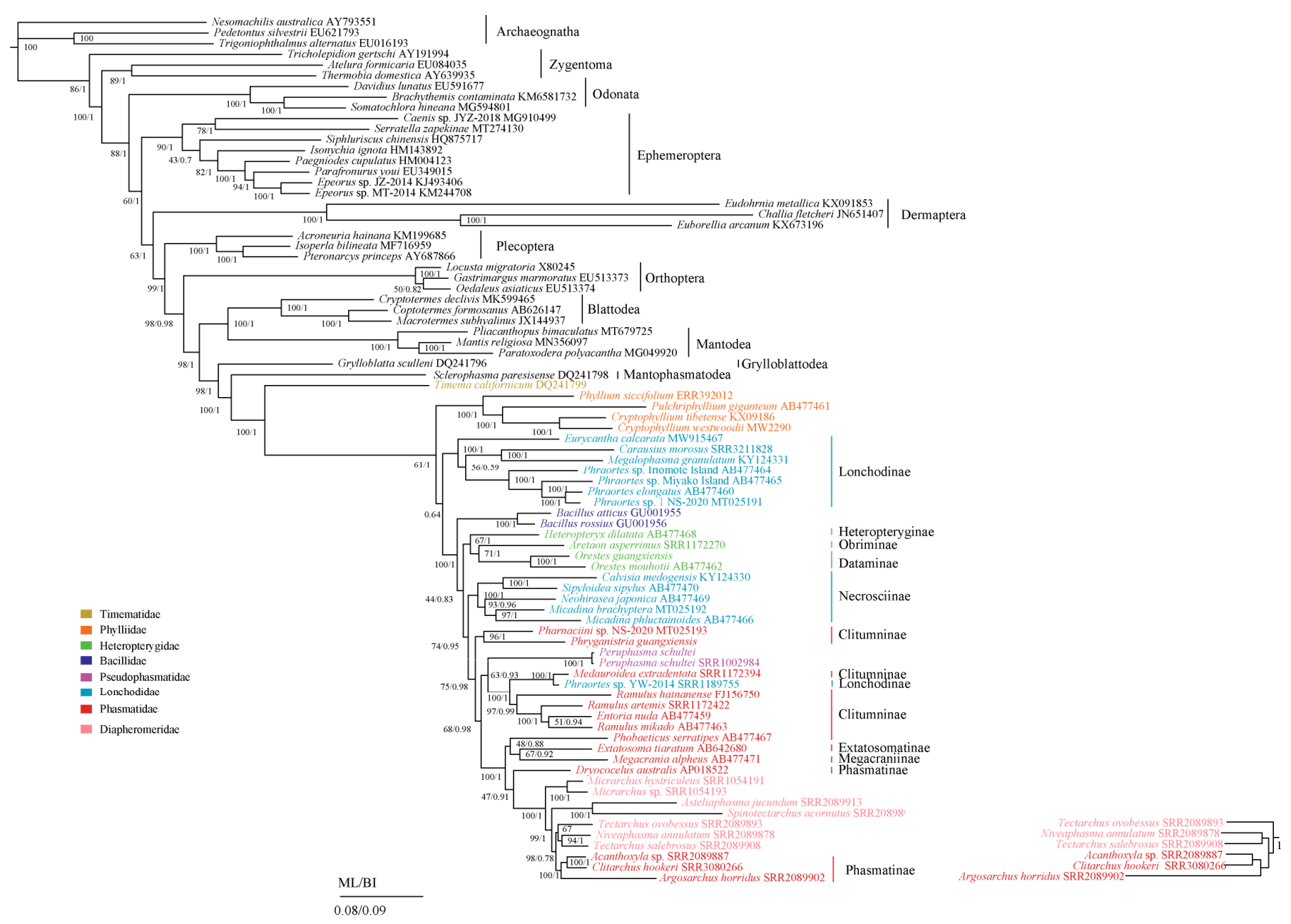

Figure 4. Phylogenetic relationships of Phasmatodea among 85 species including O. guangxiensis, Pe. schultei, and Ph. guangxiensis, inferred from ML and BI analyses based on the nucleotide dataset of the 13 mitochondrial protein-coding genes. Three species of Archaeognatha were used as outgroups. The GenBank and SRA accession numbers of all species are shown in the figure. Numbers around the nodes are the posterior probabilities of BI (right) and the bootstrap values of ML (left). Different colors in the species names correspond to the family names.

At the family level, our data supported the monophyly of Heteropterygidae but Diapheromeridae, Phasmatidae, and Lonchodidae were not recovered. Lonchodidae consists of two subfamilies, Lonchodinae and Necrosciinae, but did not form a clade, which was also reported by Forni et al., Kômoto et al., and Song et al. [6,22,33]. However, the phylogenetic relationship among Dataminae, Heteropteryginae, and Obriminae of Heteropteridae is still controversial. In this study, O. guangxiensis was the sister clade to O. mouhotii belonging to Dataminae, and Heteropteryginae was the sister clade to (Dataminae + Obriminae). Meanwhile, the same conclusion was also obtained by some research that utilized morphological data [35,114] and molecular data [115]. By contrast, Bank et al., based on three nuclear data sets $(18 \mathrm{~S}, 28 \mathrm{~S}$ and $\mathrm{H} 3)$ and four mitochondrial data genes (COX1, COX2, 12S, and 16S), were in favor of the clade of Dataminae + (Heteropteryginae + Obriminae) [116], consistent with previous results [117-119]. By contrast, other studies hypothesized that Obriminae and the clade of (Heteropteryginae + Dataminae) had a close phylogenetic relationship $[5,28,120,121]$. The Pseudophasmatidae (Pe. schultei) should be a separate clade, but our molecular phylogenetic trees showed that it was classified into Phasmatidae, and, at the same time, Phraortes sp. YW-2014 (Lonchodidae) and species of Diapheromeridae clustered into the clade of Phasmatidae. However, some studies support a sister clade of Agathemera and Pseudophasmatidae [5,28]. 
At the subfamily level, both Lonchodinae and Clitumninae were recovered as a polyphyletic group. In our analysis, we showed that Lonchodinae was not monophyletic because Phraortes sp. YW-2014 (Lonchodinae) formed a clade with Medauroidea extradentata (Clitumninae) instead of the main clade of Lonchodinae, consistent with previous analyses using molecular markers [115,122] and mitochondrial genomes [6,33,91]. Phraortes sp. YW-2014 did not cluster with other Phraortes species, probably because of a species misidentification [33]. Meanwhile, some studies, even including transcriptomes, clearly recover the monophyly of Lonchodinae $[5,26,28,114]$. Therefore, the problem of the monophyly of Lonchodinae (or not) needs further study. Ph. guangxiensis (Phasmatidae: Clitumninae) formed a sister group to Pharnaciini sp. NS-2020, but the placement of this group and Phobaeticus serratipes was distant from the main clade of Clitumninae. In our work, we failed to recover the monophyly of Clitumninae, similar to the results presented in Bradler et al., Robertson et al., and Song et al. [5,22,26].

Analyzing the phylogenetic relationships using ML and BI using the 85 species, Embioptera and Zoraptera were clustered into Phasmatodea, and the monophyly of Phasmatodea was not recovered, which was caused by long-branch attraction. After removal of the Embioptera and Zoraptera species, the phylogenetic relationships of ML and BI using the 81 species showed the monophyly of Phasmatodea and the relationships within subfamilies of Phasmatodea were supported.

\section{Conclusions}

In this study, we successfully determined the complete mitochondrial genomes of O. guangxiensis, Pe. schultei, and Ph. guangxiensis. The three stick insects shared a similar gene arrangement that has been previously reported for other stick insect species. In this study, after removing representatives of Embioptera and Zoraptera that showed long-branch attraction, BI tree and ML trees showed identical topology, except for the position of Tectarchus ovobessus (Phasmatodea). We recovered the monophyly of Phasmatodea and showed the sister-group relationship between Phasmatodea and Mantophasmatodea. We recovered the monophyly of Heteropterygidae and the paraphyly of Diapheromeridae, Phasmatidae, Lonchodidae, Lonchodinae, and Clitumninae. In this study, Peruphasma schultei (Pseudophasmatidae), Phraortes sp. YW-2014 (Lonchodidae), and species of Diapheromeridae clustered into the clade of Phasmatidae. Within Heteropterygidae, O. guangxiensis was the sister clade to O. mouhotii belonging to Dataminae, and Heteropteryginae was supported as the sister clade to (Dataminae + Obriminae). Future work may need to further explore the mitochondrial genomes of Embioptera and Zoraptera to evaluate the long-branch attraction and explore the phylogenetic relationships between Embioptera and Phasmatodea.

Supplementary Materials: The following are available online at https:/ /www.mdpi.com/article/ $10.3390 /$ insects12090779/s1, Figure S1. Inferred secondary structures of the 22 tRNA genes in O. guangxiensis mitochondrial genome. A: $\operatorname{trnI}$; B: $\operatorname{trnQ}$; C: $\operatorname{trnM}$; D: $\operatorname{trnW}$; E: $\operatorname{trnC}$; F: $\operatorname{trn} Y ;$ G: $\operatorname{trnL}$ (UUA); H: $\operatorname{trnK}$; I: $\operatorname{trnD}$; J: $\operatorname{trnG}$; K: $\operatorname{trn} A$; L: $\operatorname{trnR} ; \mathrm{M}: \operatorname{trnN}$; N: $\operatorname{trnS}$ (AGC); O: $\operatorname{trnE;~P:~} \operatorname{trnF}$; Q: $\operatorname{trnH}$; R: $\operatorname{trnT}$; S: $\operatorname{trnP} ; \mathrm{T}: \operatorname{trnS}(\mathrm{UCA}) ; \mathrm{U}: \operatorname{trn} \mathrm{L}(\mathrm{CUA}) ; \mathrm{V}$ : trnV. Figure S2. Inferred secondary structures of the 22 tRNA genes in Pe. schultei mitochondrial genome. A: $\operatorname{trnI}$; $\mathrm{B}$ : $\operatorname{trn}$; C: $\operatorname{trnM}$; D: $\operatorname{trnW}$; E: $\operatorname{trnC}$; F: $\operatorname{trn} Y ;$ G: $\operatorname{trnL}(\mathrm{UUA}) ; \mathrm{H}: \operatorname{trnK} ; \mathrm{I}: \operatorname{trnD}$; J: $\operatorname{trnG}$; K: $\operatorname{trn} \mathrm{A} ; \mathrm{L}: \operatorname{trnR} ; \mathrm{M}: \operatorname{trnN}$; N: $\operatorname{trnS}(\mathrm{AGC}) ; \mathrm{O}$ $\operatorname{trnE}$; P: $\operatorname{trnF}$; Q: $\operatorname{trnH} ; \mathrm{R}: \operatorname{trnT}$; S: $\operatorname{trnP} ; \mathrm{T}: \operatorname{trnS}(\mathrm{UCA}) ; \mathrm{U}: \operatorname{trn} \mathrm{L}(\mathrm{CUA}) ; \mathrm{V}: \operatorname{trnV}$. Figure S3. Inferred secondary structures of the 22 tRNA genes in Ph. guangxiensis mitochondrial genome. A: trnI; B: $\operatorname{trnQ;~C:~} \operatorname{trnM}$; D: $\operatorname{trn} W ; \mathrm{E}: \operatorname{trnC}$; F: $\operatorname{trn} Y$; G: $\operatorname{trnL}(\mathrm{UUA}) ; \mathrm{H}: \operatorname{trnK}$; I: $\operatorname{trnD}$; J: $\operatorname{trnG}$; K: $\operatorname{trn} \mathrm{A}$; L: $\operatorname{trnR}$; M: $\operatorname{trnN}$; N: $\operatorname{trnS}(A G C) ; O: \operatorname{trnE}$; P: $\operatorname{trnF}$; Q: $\operatorname{trnH}$; R: $\operatorname{trnT}$; S: $\operatorname{trnP}$; T: $\operatorname{trnS}(\mathrm{UCA}) ; \mathrm{U}: \operatorname{trn} \mathrm{L}$ (CUA); V: $\operatorname{trnV}$. Figure S4. The possible secondary structure of the tandem repeat in the control regions. (A) the repeat unit (176 bp) in O. guangxiensis. (B) the repeat unit (64 bp) in Pe. schultei. (C) the repeat unit (106 bp) in Ph. guangxiensis. (D) the repeat unit (128 bp) in Entoria nuda. (E) the repeat unit (149 bp) in Ramulus mikado. (F) the repeat unit (125 bp) in Ramulus irregulariterdentatus. (G) the repeat unit (193 bp) in Phobaeticus serratipes. (H) the repeat unit (106 bp) in Micadina phluctainoides. (I) the repeat unit (70 bp) in Phraortes elongatus. (J) the repeat unit (97 bp) in Phraortes sp. Iriomote Island. (K) the 
repeat unit $(21 \mathrm{bp})$ in Heteropteryx dilatata. (L) the repeat unit (149 bp) in Heteropteryx dilatata. (M) the repeat unit (64 bp) in Ramulus hainanense. (N) the repeat unit (50 bp) in Megacrania alpheus. $(\mathrm{O})$ the repeat unit (189 bp) in Extatosoma tiaratum. (P) the repeat unit (32 bp) in Eurycantha calcarata. Figure S5. Phylogenetic relationships of Phasmatodea inferred from ML analysis including Embioptera and Zoraptera. Figure S6. Phylogenetic relationships of Phasmatodea inferred from BI analysis including Embioptera and Zoraptera. Table S1. Specific primers used to amplify the mitochondrial genomes of O. guangxiensis, Pe. schultei and Ph. guangxiensis. Table S2. Species of Phasmatodea used to construct the phylogenetic relationships along with SRA numbers. Table S3. Location of features in the mtDNA of O. guangxiensis. Table S4. Location of features in the mtDNA of Pe. schultei. Table S5. Location of features in the mtDNA of Ph. guangxiensis. Table S6. Mitochondrial genome comparisons of Phasmatodea species. Table S7. The codon numbers and relative synonymous codon usage in mitochondrial protein-coding genes.

Author Contributions: Conceptualization, J.-Y.Z., D.-N.Y., K.-K.X. and Q.-P.C.; Methodology, K.-K.X., J.-Y.Z. and S.P.G.A.; Statistical analysis, J.-Y.Z., K.-K.X., Q.-P.C., J.-Y.G. and S.P.G.A.; Investigation, D.-N.Y. and J.-Y.G.; Data curation, K.-K.X., Q.-P.C., S.P.G.A. and K.B.S.; Writing-original draft preparation, K.-K.X., Q.-P.C. and K.B.S.; Writing-review and editing, J.-Y.Z., D.-N.Y., K.-K.X., Q.-P.C., S.P.G.A., J.-Y.G. and K.B.S.; Maps and graphics, K.-K.X., Q.-P.C. and J.-Y.G.; Project administration, J.-Y.Z., D.-N.Y. and K.B.S.; Funding acquisition, J.-Y.Z. and D.-N.Y. All authors have read and agreed to the published version of the manuscript.

Funding: This work was supported by the Natural Science Foundation of Zhejiang Province (LY18C040004), the College Students' Innovation and Entrepreneurship Project of China (201910345030 and 202010345026), and the College Students' Innovation and Entrepreneurship Project of Zhejiang Province (202010345R128). The funders had no role in study design, data collection and analysis, decision to publish, or preparation of the manuscript.

Institutional Review Board Statement: Not applicable.

Informed Consent Statement: Not applicable.

Data Availability Statement: Not applicable.

Acknowledgments: We are grateful to Yue Ma for his help in the data processing.

Conflicts of Interest: The authors declare no conflict of interest.

\section{References}

1. Bradler, S.; Buckley, T. Biodiversity of Phasmatodea. In Insect Biodiversity; Adler, P.H., Foottit, R.G., Eds.; John Wiley and Sons Ltd.: Hoboken, NJ, USA, 2018; pp. 281-313.

2. Brock, P.D.; Büscher, T.; Baker, E. Phasmida Species File Online. Version 5.0/5.0. Available online: http:/ / Phasmida.SpeciesFile. org (accessed on 15 August 2021).

3. Bragg, P.E. The phasmid database version 1.5. In Phasmid Studies; Bragg, P.E., Ed.; Phasmid Study Group: Derbyshire, UK, 1995; Volume 3, pp. 41-42.

4. Brock, P.D.; Hasenpusch, J.W. The Complete Field Guide to Stick and Leaf Insects of Australia; CSIRO Publishing: Clayton, Australia, 2009.

5. Robertson, J.A.; Bradler, S.; Whiting, M.F. Evolution of oviposition techniques in stick and leaf insects (Phasmatodea). Front. Ecol. Evol. 2018, 6, 216. [CrossRef]

6. Kômoto, N.; Yukuhiro, K.; Ueda, K.; Tomita, S. Exploring the molecular phylogeny of phasmids with whole mitochondrial genome sequences. Mol. Phylogenet. Evol. 2011, 58, 43-52. [CrossRef] [PubMed]

7. Beutel, R.G.; Gorb, S.N. Ultrastructure of attachment specializations of hexapods (Arthropoda): Evolutionary patterns inferred from a revised ordinal phylogeny. J. Zool. Syst. Evol. Res. 2001, 39, 177-207. [CrossRef]

8. Terry, M.D.; Whiting, M.F. Mantophasmatodea and phylogeny of the lower neopterous insects. Cladistics 2005, 21, 240-257. [CrossRef]

9. Klug, R.; Bradler, S. The pregenital abdominal musculature in phasmids and its implications for the basal phylogeny of Phasmatodea (Insecta: Polyneoptera). Org. Divers. Evol. 2006, 6, 171-184. [CrossRef]

10. Mashimo, Y.; Beutel, R.G.; Dallai, R.; Lee, C.Y.; Machida, R. Embryonic development of Zoraptera with special reference to external morphology, and its phylogenetic implications (Insecta). J. Morphol. 2014, 275, 295-312. [CrossRef] [PubMed]

11. Misof, B.; Liu, S.; Meusemann, K.; Peters, R.S.; Donath, A.; Mayer, C.; Frandsen, P.B.; Ware, J.; Flouri, T.; Beutel, R.G.; et al. Phylogenomics resolves the timing and pattern of insect evolution. Science 2014, 346, 763-767. [CrossRef] [PubMed] 
12. Wipfler, B.; Letsch, H.; Frandsen, P.B.; Kapli, P.; Mayer, C.; Bartel, D.; Buckley, T.R.; Donath, A.; Edgerly-Rooks, J.S.; Fujita, M.; et al. Evolutionary history of Polyneoptera and its implications for our understanding of early winged insects. Proc. Natl. Acad. Sci. USA 2019, 116, 3024-3029. [CrossRef] [PubMed]

13. Klass, K.D.; Zompro, O.; Kristensen, N.P.; Adis, J. Mantophasmatodea: A new insect order with extant members in the Afrotropics. Science 2002, 296, 1456-1459. [CrossRef]

14. Cameron, S.L.; Barker, S.C.; Whiting, M.F. Mitochondrial genomics and the new insect order Mantophasmatodea. Mol. Phylogenet. Evol. 2006, 38, 274-279. [CrossRef]

15. Plazzi, F.; Ricci, A.; Passamonti, M. The mitochondrial genome of Bacillus stick insects (Phasmatodea) and the phylogeny of orthopteroid insects. Mol. Phylogenet. Evol. 2011, 58, 304-316. [CrossRef]

16. Yu, D.N.; Yu, P.P.; Zhang, L.P.; Storey, K.B.; Gao, X.Y.; Zhang, J.Y. Increasing 28 mitogenomes of Ephemeroptera, Odonata and Plecoptera support the Chiastomyaria hypothesis with three different outgroup combinations. Peer] 2021, 9, e11402. [CrossRef]

17. Engel, M.S.; Grimaldi, D.A. A winged Zorotypus in Miocene amber from the Dominican Republic (Zoraptera: Zorotypidae), with discussion on relationships of and within the order. Acta Geol. Hisp. 2000, 35, 149-164.

18. Yoshizawa, K. Monophyletic Polyneoptera recovered by wing base structure. Syst. Entomol. 2011, 36, 377-394. [CrossRef]

19. Chen, S.; Zhang, W.W.; Shih, C.K.; Ren, D. Two new species of Archipseudophasmatidae (Insecta: Phasmatodea) from Upper Cretaceous Myanmar amber. Cretac. Res. 2017, 73, 65-70. [CrossRef]

20. Ma, C.; Wang, Y.Y.; Wu, C.; Kang, L.; Liu, C.X. The compact mitochondrial genome of Zorotypus medoensis provides insights into phylogenetic position of Zoraptera. BMC Genom. 2014, 15, 1156. [CrossRef]

21. Song, S.N.; Tang, P.; Wei, S.J.; Chen, X.X. Comparative and phylogenetic analysis of the mitochondrial genomes in basal hymenopterans. Sci. Rep. 2016, 6, 1. [CrossRef] [PubMed]

22. Song, N.; Li, X.H.; Na, R.S. Mitochondrial genomes of stick insects (Phasmatodea) and phylogenetic considerations. PLoS ONE 2020, 15, e0240186. [CrossRef]

23. Buckley, T.; Attanayake, D.; Bradler, S. Extreme convergence in stick insect evolution: Phylogenetic placement of the Lord Howe Island tree lobster. Proc. R. Soc. B 2009, 276, 1055-1062. [CrossRef]

24. Engel, M.S.; Wang, B.; Alqarni, A.S. A thorny, 'anareolate' stick-insect (Phasmatidae sl) in Upper Cretaceous amber from Myanmar, with remarks on diversification times among Phasmatodea. Cretaceous Res. 2016, 63, 45-53. [CrossRef]

25. Tilgner, E. Systematics of Phasmida. Ph.D. Dissertation, University of Georgia, Athens, Georgia, 2002.

26. Bradler, S.; Robertson, J.A.; Whiting, M.F. A molecular phylogeny of Phasmatodea with emphasis on Necrosciinae, the most species-rich subfamily of stick insects. Syst. Entomol. 2014, 39, 205-222. [CrossRef]

27. Zompro, O. A key to the genera of the Phasmatodea: Areolatae (Insecta). In Phasmida Studies; Bragg, P.E., Ed.; 0966-0011; Phasmida Studies Group: Derbyshire, UK, 2005; Volume 12, pp. 11-25.

28. Simon, S.; Letsch, H.; Bank, S.; Buckley, T.R.; Donath, A.; Liu, S.; Machida, R.; Meusemann, K.; Misof, B.; Podsiadlowski, L.; et al. Old world and new world Phasmatodea: Phylogenomics resolve the evolutionary history of stick and leaf Insects. Front. Ecol. Evol. 2019, 7, 345. [CrossRef]

29. Tihelka, E.; Cai, C.Y.; Giacomelli, M.; Pisani, D.; Donoghue, P.C.J. Integrated phylogenomic and fossil evidence of stick and leaf insects (Phasmatodea) reveal a Permian-Triassic co-origination with insectivores. Roy. Soc. Open. Sci. 2020, 7, 201689. [CrossRef]

30. Tomita, S.; Yukuhiro, K.; Kômoto, N. The mitochondrial genome of a stick insect Extatosoma tiaratum (Phasmatodea) and the phylogeny of polyneopteran insects. J. Insect Biotechnol. Sericol. 2011, 80, 79-88.

31. Friedemann, K.; Wipfler, B.; Bradler, S.; Beutel, R.G. On the head morphology of Phyllium and the phylogenetic relationships of Phasmatodea (Insecta). Acta Zool. 2012, 93, 184-199. [CrossRef]

32. Yang, H.R.; Yin, X.C.; Lin, X.D.; Wang, C.; Shih, C.K.; Zhang, W.W.; Ren, D.; Gao, T.P. Cretaceous winged stick insects clarify the early evolution of Phasmatodea. Proc. R. Soc. B 2019, 286, 20191085. [CrossRef]

33. Forni, G.; Plazzi, F.; Cussigh, A.; Conle, O.; Hennemann, F.; Luchetti, A.; Mantovani, B. Phylomitogenomics provides new perspectives on the Euphasmatodea radiation (Insecta: Phasmatodea). Mol. Phylogenet. Evol. 2020, 155, 106983. [CrossRef]

34. Kômoto, N.; Yukuhiro, K.; Tomita, S. Novel gene rearrangements in the mitochondrial genome of a webspinner, Aposthonia japonica (Insecta: Embioptera). Genome 2012, 55, 222-233. [CrossRef]

35. Zompro, O. Revision of the genera of the Areolatae, including the status of Timema and Agathemera (Insecta, Phasmatodea). Abh. Des Nat. Ver. Hambg. 2004, 37, 85-116.

36. Song, N.; Li, H.; Song, F.; Cai, W. Molecular phylogeny of Polyneoptera (Insecta) inferred from expanded mitogenomic data. Sci. Rep. 2016, 6, 36175. [CrossRef] [PubMed]

37. Li, T.; Hua, J.; Wright, A.M.; Cui, Y.; Xie, Q.; Bu, W.; Hillis, D.M. Long-branch attraction and the phylogeny of true water bugs (Hemiptera: Nepomorpha) as estimated from mitochondrial genomes. BMC Ecol. Evol. 2014, 14, 99. [CrossRef] [PubMed]

38. Boore, J.L. Animal mitochondrial genomes. Nucleic Acids Res. 1999, 27, 1767-1780. [CrossRef] [PubMed]

39. Simon, C.; Frati, F.; Beckenbach, A.; Crespi, B.; Liu, H.; Flook, P. Evolution, weighting, and phylogenetic utility of mitochondrial gene sequences and a compilation of conserved polymerase chain reaction primers. Ann. Entomol. Soc. Am. 1994, 87, 651-701. [CrossRef]

40. Gissi, C.; Iannelli, F.; Pesole, G. Evolution of the mitochondrial genome of Metazoa as exemplified by comparison of congeneric species. Heredity 2008, 101, 301-320. [CrossRef] 
41. Cameron, S.L. Insect mitochondrial genomics: Implications for evolution and phylogeny. Annu. Rev. Entomol. 2014, 59, 95-117. [CrossRef] [PubMed]

42. Cameron, S.L.; Lambkin, C.L.; Barker, S.C.; Whiting, M.F. A mitochondrial genome phylogeny of Diptera: Whole genome sequence data accurately resolve relationships over broad timescales with high precision. Syst. EntomoL. 2007, 32, 40-59. [CrossRef]

43. Fenn, J.D.; Song, H.J.; Cameron, S.L.; Whiting, M.F. A preliminary mitochondrial genome phylogeny of Orthoptera (Insecta) and approaches to maximizing phylogenetic signal found within mitochondrial genome data. Mol. Phylogenet. Evol. 2008, 49, 59-68. [CrossRef]

44. Castro, L.R.; Dowton, M.K. Mitochondrial genomes in the Hymenoptera and their utility as phylogenetic markers. Syst. Entomol. 2007, 32, 60-69. [CrossRef]

45. Pons, J.; Ribera, I.; Bertranpetit, J.; Balke, M. Nucleotide substitution rates for the full set of mitochondrial protein-coding genes in Coleoptera. Mol. Phylogenet. Evol. 2010, 56, 796-807. [CrossRef]

46. Zhang, L.P.; Yu, D.N.; Storey, K.B.; Cheng, H.Y.; Zhang, J.Y. Higher tRNA gene duplication in mitogenomes of praying mantises (Dictyoptera, Mantodea) and the phylogeny within Mantodea. Int. J. Biol. Macromol. 2018, 111, 787-795. [CrossRef]

47. Lalitha, S. Primer Premier 5. Biotech Softw. Internet Rep. 2000, 1, 270-272. [CrossRef]

48. Burland, T.G. DNASTAR's Lasergene sequence analysis software. In Bioinformatics Methods and Pprotocols; Misener, S., Krawetz, S.A., Eds.; Humana Press: Totowa, NJ, USA, 1999; Volume 132, pp. 71-91.

49. Bernt, M.; Donath, A.; Jühling, F.; Externbrink, F.; Lorentz, C.; Fritzsch, G.; Pütz, J.; Middendorf, M.; Stadler, P.F. MITOS: Improved de novo metazoan mitochondrial genome annotation. Mol. Phylogenet. Evol. 2013, 69, 313-319. [CrossRef] [PubMed]

50. Thompson, J.D.; Gibson, T.J.; Plewniak, F.; Jeanmougin, F.; Higgins, D.G. The CLUSTAL_X windows interface: Flexible strategies for multiple sequence alignment aided by quality analysis tools. Nucleic Acids Res. 1997, 25, 4876-4882. [CrossRef] [PubMed]

51. Kumar, S.; Stecher, G.; Tamura, K. Mega 7: Molecular evolutionary genetics analysis version 7.0 for bigger datasets. Mol. Biol. Evol. 2016, 33, 1870-1874. [CrossRef]

52. Cameron, S.L. How to sequence and annotate insect mitochondrial genomes for systematic and comparative genomics research. Syst. Entomol. 2014, 39, 400-411. [CrossRef]

53. Zhang, D.; Gao, F.; Jakovlić, I.; Zou, H.; Zhang, J.; Li, W.X.; Wang, G.T. PhyloSuite: An integrated and scalable desktop platform for streamlined molecular sequence data management and evolutionary phylogenetics studies. Mol. Ecol. Resour. 2020, 20, 348-355. [CrossRef]

54. Perna, N.T.; Kocher, T.D. Patterns of nucleotide composition at four fold degenerate sites of animal mitochondrial genomes. J. Mol. Evol. 1995, 41, 353-358. [CrossRef]

55. Cameron, S.L.; Miller, K.B.; D’Haese, C.A.; Whiting, M.F.; Barker, S.C. Mitochondrial genome data alone are not enough to unambiguously resolve the relationships of Entognatha, Insecta and Crustacea sensu lato (Arthropoda). Cladistics 2004, 20, 534-557. [CrossRef]

56. Zhang, J.Y.; Song, D.X.; Zhou, K.Y. The complete mitochondrial genome of the bristletail Pedetontus silvestrii (Archaeognatha: Machilidae) and an examination of mitochondrial gene variability within four Bristletails. Ann. Entomol. Soc. Am. 2008, 101, 1131-1136. [CrossRef]

57. Carapelli, A.; Liò, P.; Nardi, F.; van der Wath, E.; Frati, F. Phylogenetic analysis of mitochondrial protein coding genes confirms the reciprocal paraphyly of Hexapoda and Crustacea. BMC Ecol. Evol. 2007, 7, S8. [CrossRef]

58. Nardi, F.; Spinsanti, G.; Boore, J.L.; Carapelli, A.; Dallai, R.; Frati, F. Hexapod origins: Monophyletic or paraphyletic? Science 2003, 299, 1887-1889. [CrossRef]

59. Comandi, S.; Carapelli, A.; Podsiadlowski, L.; Nardi, F.; Frati, F. The complete mitochondrial genome of Atelura formicaria (Hexapoda: Zygentoma) and the phylogenetic relationships of basal insects. Gene 2009, 439, 25-34. [CrossRef]

60. Cook, C.E.; Yue, Q.; Akam, M. Mitochondrial genomes suggest that hexapods and crustaceans are mutually paraphyletic. Proc. R. Soc. B 2005, 272, 1295-1304. [CrossRef]

61. Yu, P.P.; Cheng, X.F.; Ma, Y.; Yu, D.N.; Zhang, J.Y. The complete mitochondrial genome of Brachythemis contaminata (Odonata: Libellulidae). Mitochondrial DNA Part A 2016, 27, 2272-2273.

62. Li, D.; Qin, J.-C.; Zhou, C.-F. The phylogeny of Ephemeroptera in Pterygota revealed by the mitochondrial genome of Siphluriscus chinensis (Hexapoda: Insecta). Gene 2014, 545, 132-140. [CrossRef]

63. Xu, X.D.; Jia, Y.Y.; Cao, S.S.; Zhang, Z.Y.; Storey, K.B.; Yu, D.N.; Zhang, J.Y. Six complete mitochondrial genomes of mayflies from three genera of Ephemerellidae (Insecta: Ephemeroptera) with inversion and translocation of trnI rearrangement and their phylogenetic relationships. PeerJ 2020, 8, e9740. [CrossRef]

64. Zhang, J.Y.; Zhou, C.F.; Gai, Y.H.; Song, D.X.; Zhou, K.Y. The complete mitochondrial genome of Parafronurus youi (Insecta: Ephemeroptera) and phylogenetic position of the Ephemeroptera. Gene 2008, 424, 18-24. [CrossRef] [PubMed]

65. Cai, Y.Y.; Gao, Y.J.; Zhang, L.P.; Yu, D.N.; Storey, K.B.; Zhang, J.Y. The mitochondrial genome of Caenis sp. (Ephemeroptera: Caenidae) and the phylogeny of Ephemeroptera in Pterygota. Mitochondrial DNA Part B 2018, 3, 577-579. [CrossRef]

66. Tang, M.; Tan, M.H.; Meng, G.L.; Yang, S.Z.; Su, X.; Liu, S.L.; Song, W.H.; Li, Y.Y.; Wu, Q.; Zhang, A.B.; et al. Multiplex sequencing of pooled mitochondrial genomes-a crucial step toward biodiversity analysis using mito-metagenomics. Nucleic Acids Res. 2014, 42, e166. [CrossRef] 
67. Stewart, J.B.; Beckenbach, A.T. Insect mitochondrial genomics 2: The complete mitochondrial genome sequence of a giant stonefly, Pteronarcys princeps, asymmetric directional mutation bias, and conserved plecopteran A+T-region elements. Genome 2006, 49, 815-824. [CrossRef]

68. Huang, M.C.; Wang, Y.Y.; Liu, X.Y.; Li, W.H.; Kang, Z.H.; Wang, K.; Li, X.K.; Yang, D. The complete mitochondrial genome and its remarkable secondary structure for a stonefly Acroneuria hainana Wu (Insecta: Plecoptera, Perlidae). Gene 2015, 557, 52-60. [CrossRef]

69. Chen, Z.T.; Zhao, M.Y.; Xu, C.; Du, Y.Z. Molecular phylogeny of Systellognatha (Plecoptera: Arctoperlaria) inferred from mitochondrial genome sequences. Int. J. Biol. Macromol. 2018, 111, 542-547. [CrossRef]

70. Ma, C.; Liu, C.X.; Yang, P.C.; Kang, L. The complete mitochondrial genomes of two band-winged grasshoppers, Gastrimargus marmoratus and Oedaleus asiaticus. BMC Genom. 2009, 10, 156. [CrossRef]

71. Jia, Y.Y.; Zhang, L.P.; Xu, X.D.; Dai, X.Y.; Yu, D.N.; Storey, K.B.; Zhang, J.Y. The complete mitochondrial genome of Mantis religiosa (Mantodea: Mantidae) from Canada and its phylogeny. Mitochondrial DNA Part B 2019, 4, 3797-3799. [CrossRef]

72. Guan, J.Y.; Jia, Y.Y.; Zhang, Z.Y.; Cao, S.S.; Ma, J.L.; Zhang, J.Y.; Yu, D.N. The complete mitochondrial genome of Xanthomantis bimaculata (Mantodea: Iridopterygidae) and its phylogeny. Mitochondrial DNA Part B 2020, 5, 3079-3081. [CrossRef] [PubMed]

73. He, P.S.; Zhang, L.; Wen, Y.; Li, T.; Hu, K.P.; Zhou, Q.; Wang, J.G. The complete mitochondrial genome of Cryptotermes declivis Tsai et Chen (Isoptera: Kalotermitidae). Mitochondrial DNA Part B 2019, 4, 2564-2565. [CrossRef]

74. Tokuda, G.; Isagawa, H.; Sugio, K. The complete mitogenome of the Formosan termite, Coptotermes formosanus Shiraki. Insectes Sociaux 2012, 59, 17-24. [CrossRef]

75. Cameron, S.L.; Lo, N.; Bourguignon, T.; Svenson, G.J.; Evans, T.A. A mitochondrial genome phylogeny of termites (Blattodea: Termitoidae): Robust support for interfamilial relationships and molecular synapomorphies define major clades. Mol. Phylogenet. Evol. 2012, 65, 163-173. [CrossRef]

76. Wan, X.L.; Kim, M.I.; Kim, M.J.; Kim, I. Complete mitochondrial genome of the free-living earwig, Challia fletcheri (Dermaptera: Pygidicranidae) and phylogeny of Polyneoptera. PLOS ONE 2012, 7, e42056.

77. Flook, P.K.; Rowell, C.H.F.; Gellissen, G. The sequence, organization, and evolution of the Locusta migratoria mitochondrial genome. J. Mol. Evol. 1995, 41, 928-941. [CrossRef] [PubMed]

78. Song, H.; Amédégnato, C.; Cigliano, M.M.; Desutter-Grandcolas, L.; Heads, S.W.; Huang, Y.; Otte, D.; Whiting, M.F. 300 million years of diversification: Elucidating the patterns of orthopteran evolution based on comprehensive taxon and gene sampling. Cladistics 2015, 31, 621-651. [CrossRef]

79. Heath, T.A.; Hedtke, S.M.; Hillis, D.M. Taxon sampling and the accuracy of phylogenetic analyses. J. Syst. Evol. 2008, 46, 239-257.

80. Li, Y.W.; Yu, L.; Zhang, Y.P. “Long-branch Attraction” artifact in phylogenetic reconstruction. Yi Chuan 2007, $29,659-667$. [CrossRef]

81. Lartillot, N.; Brinkmann, H.; Philippe, H. Suppression of long-branch attraction artefacts in the animal phylogeny using a site-heterogeneous model. BMC Ecol. Evol. 2007, 7, S4. [CrossRef]

82. Castresana, J. Selection of conserved blocks from multiple alignments for their use in phylogenetic analysis. Mol. Biol. Evol. 2000, 17, 540-552. [CrossRef]

83. Kearse, M.; Moir, R.; Wilson, A.; Stones-Havas, S.; Cheung, M.; Sturrock, S.; Buxton, S.; Cooper, A.; Markowitz, S.; Duran, C.; et al. Geneious Basic: An integrated and extendable desktop software platform for the organization and analysis of sequence data. Bioinformatics 2012, 28, 1647-1649. [CrossRef] [PubMed]

84. Xia, X.; Xie, Z. DAMBE: Software package for data analysis in molecular biology and evolution. J. Hered. 2001, 92, 371-373. [CrossRef] [PubMed]

85. Kalyaanamoorthy, S.; Minh, B.Q.; Wong, T.K.F.; von Haeseler, A.; Jermiin, L.S. ModelFinder: Fast model selection for accurate phylogenetic estimates. Nat. Methods 2017, 14, 587-589. [CrossRef]

86. Minh, B.Q.; Schmidt, H.A.; Chernomor, O.; Schrempf, D.; Woodhams, M.D.; von Haeseler, A.; Lanfear, R. IQ-TREE 2: New models and efficient methods for phylogenetic inference in the genomic era. Mol. Biol. Evol. 2020, 37, 1530-1534. [CrossRef] [PubMed]

87. Ronquist, F.; Teslenko, M.; van der Mark, P.; Ayres, D.L.; Darling, A.; Höhna, S.; Larget, B.; Liu, L.; Suchard, M.A.; Huelsenbeck, J.P. MrBayes 3.2: Efficient Bayesian phylogenetic inference and model choice across a large model space. Syst. Biol. 2012, 61, 539-542. [CrossRef]

88. Cumming, R.T.; Bank, S.; Bresseel, J.; Constant, J.; Tirant, S.L.; Dong, Z.W.; Sonet, G.; Bradler, S. Cryptophyllium, the hidden leaf insects-Descriptions of a new leaf insect genus and thirteen species from the former celebicum species group (Phasmatodea, Phylliidae). Zookeys 2021, 1018, 1-179. [CrossRef] [PubMed]

89. Dong, Z.W.; Li, J.; He, J.W.; Liu, G.C.; Mao, C.Y.; Zhao, R.P.; Li, X.Y. The mitochondrial genome of a leaf insect Phyllium westwoodii (Phasmatodea: Phylliidae) in Southeast Asia. Mitochondrial DNA Part B 2021, 6, 888-890. [CrossRef]

90. Mikheyev, A.S.; Zwick, A.; Magrath, M.J.L.; Grau, M.L.; Qiu, L.; Su, Y.N.; Yeates, D. Museum genomics confirms that the Lord Howe Island stick insect survived extinction. Curr. Biol. 2017, 27, 3157-3161. [CrossRef] [PubMed]

91. Zhou, Z.J.; Guan, B.; Chai, J.Y.; Che, X.T. Next-generation sequencing data used to determine the mitochondrial genomes and a preliminary phylogeny of Verophasmatodea insects. J. Asia-Pac. Entomol. 2017, 20, 713-719. [CrossRef]

92. Wolstenholme, D.R. Animal Mitochondrial DNA: Structure and Evolution. Int. Rev. Cytol. 1992, 141, 173-216. [PubMed]

93. Nardi, F.; Carapelli, A.; Fanciulli, P.P.; Dallai, R.; Frati, F. The complete mitochondrial DNA sequence of the basal hexapod Tetrodontophora bielanensis: Evidence for heteroplasmy and tRNA translocations. Mol. Biol. Evol. 2001, 18, 1293-1304. [CrossRef] 
94. Ma, Y.; He, K.; Yu, P.P.; Yu, D.N.; Cheng, X.F.; Zhang, J.Y. The complete mitochondrial genomes of three bristletails (Insecta: Archaeognatha): The paraphyly of Machilidae and insights into Archaeognathan phylogeny. PLoS ONE 2015, 10, e0117669. [CrossRef]

95. Cheng, X.F.; Zhang, L.P.; Yu, D.N.; Storey, K.B.; Zhang, J.Y. The complete mitochondrial genomes of four cockroaches (Insecta: Blattodea) and phylogenetic analyses within cockroaches. Gene 2016, 586, 115-122. [CrossRef]

96. Ye, F.; Lan, X.E.; Zhu, W.B.; You, P. Mitochondrial genomes of praying mantises (Dictyoptera, Mantodea): Rearrangement, duplication, and reassignment of tRNA genes. Sci. Rep. 2016, 6, 25634. [CrossRef]

97. Anderson, S.; Bankier, A.T.; Barrell, B.G.; de Bruijn, M.H.L.; Coulson, A.R.; Drouin, J.; Eperon, I.C.; Nierlich, D.P.; Roe, B.A.; Sanger, F.; et al. Sequence and organization of the human mitochondrial genome. Nature 1981, 290, 457-465. [CrossRef] [PubMed]

98. Powell, J.R.; Moriyama, E.N. Evolution of codon usage bias in Drosophila. Proc. Natl. Acad. Sci. USA 1997, 94, 7784-7790. [CrossRef]

99. Rao, Y.S.; Wu, G.Z.; Wang, Z.F.; Chai, X.W.; Nie, Q.H.; Zhang, X.Q. Mutation bias is the driving force of codon usage in the Gallus gallus genome. DNA Res. 2011, 18, 499-512. [CrossRef]

100. Du, C.; Zhang, L.F.; Lu, T.; Ma, J.G.; Zeng, C.J.; Yue, B.S.; Zhang, X.Y. Mitochondrial genomes of blister beetles (Coleoptera, Meloidae) and two large intergenic spacers in Hycleus genera. BMC Genom. 2017, 18, 698. [CrossRef] [PubMed]

101. Gao, X.Y.; Cai, Y.Y.; Yu, D.N. Characteristics of the complete mitochondrial genome of Suhpalacsa longialata (Neuroptera, Ascalaphidae) and its phylogenetic implications. PeerJ 2018, 6, e5914. [CrossRef]

102. Wang, J.; Dai, X.Y.; Xu, X.D.; Zhang, Z.Y.; Yu, D.N.; Storey, K.B.; Zhang, J.Y. The complete mitochondrial genomes of five longicorn beetles (Coleoptera: Cerambycidae) and phylogenetic relationships within Cerambycidae. PeerJ 2019, 7, e7633. [CrossRef]

103. Hanada, T.; Suzuki, T.; Yokogawa, T.; Takemoto-Hori, C.; Sprinzl, M.; Watanabe, K. Translation ability of mitochondrial tRNAs ${ }^{\text {Ser }}$ with unusual secondary structures in an in vitro translation system of bovine mitochondria. Genes Cells 2001, 6, 1019-1030. [CrossRef]

104. McClain, W.H. Surprising contribution to aminoacylation and translation of non-Watson-Crick pairs in tRNA. Proc. Natl. Acad. Sci. USA 2006, 103, 4570-4575. [CrossRef]

105. Taanman, J.W. The mitochondrial genome: Structure, transcription, translation and replication. BBA-Bioenerg. 1999, 1410, 103-123. [CrossRef]

106. Yukuhiro, K.; Sezutsu, H.; Itoh, M.; Shimizu, K.; Banno, Y. Significant levels of sequence divergence and gene rearrangements have occurred between the mitochondrial genomes of the wild mulberry silkmoth, Bombyx mandarina, and its close relative, the domesticated silkmoth, Bombyx mori. Mol. Biol. Evol. 2002, 19, 1385-1389. [CrossRef]

107. Saito, S.; Tamura, K.; Aotsuka, T. Replication origin of mitochondrial DNA in Insects. Genetics 2005, 171, 1695-1705. [CrossRef] [PubMed]

108. Hofacker, I.L.; Fekete, M.; Stadler, P.F. Secondary structure prediction for aligned RNA sequences. J. Mol. Biol. 2002, 319, 1059-1066. [CrossRef]

109. Bernhart, S.H.; Hofacker, I.L.; Will, S.; Gruber, A.R.; Stadler, P.F. RNAalifold: Improved consensus structure prediction for RNA alignments. BMC Bioinform. 2008, 9, 474. [CrossRef] [PubMed]

110. Gruber, A.R.; Lorenz, R.; Bernhart, S.H.; Neuböck, R.; Hofacker, I.L. The Vienna RNA websuite. Nucleic Acids Res. 2008, 36, 70-74. [CrossRef]

111. Moritz, C.; Brown, W.M. Tandem duplications in animal mitochondrial DNAs: Variation in incidence and gene content among lizards. Proc. Natl. Acad. Sci. USA 1987, 84, 7183-7187. [CrossRef]

112. Misof, B.; Niehuis, O.; Bischoff, I.; Rickert, A.; Erpenbeck, D.; Staniczek, A. Towards an 18 S phylogeny of hexapods: Accounting for group-specific character covariance in optimized mixed nucleotide/doublet models. Zoology 2007, 110, 409-429. [CrossRef]

113. Simon, S.; Blanke, A.; Meusemann, K. Reanalyzing the Palaeoptera problem-the origin of insect flight remains obscure. Arthropod Struct. Dev. 2018, 47, 328-338. [CrossRef] [PubMed]

114. Goldberg, J.; Bresseel, J.; Constant, J.; Kneubühler, B.; Leubner, F.; Michalik, P.; Bradler, S. Extreme convergence in egg-laying strategy across insect orders. Sci. Rep. 2015, 5, 7825. [CrossRef] [PubMed]

115. Glaw, F.; Hawlitschek, O.; Dunz, A.; Goldberg, J.; Bradler, S. When giant stick insects play with colors: Molecular phylogeny of the Achriopterini and description of two new Splendid species (Phasmatodea: Achrioptera) from Madagascar. Front. Ecol. Evol. 2019, 7. [CrossRef]

116. Bank, S.; Buckley, T.R.; Büscher, T.H.; Bresseel, J.; Constant, J.; de Haan, M.; Dittmar, D.; Dräger, H.; Kahar, R.S.; Kang, A.; et al. Reconstructing the nonadaptive radiation of an ancient lineage of ground-dwelling stick insects (Phasmatodea: Heteropterygidae). Syst. Entomol. 2021, 46, 487-507. [CrossRef]

117. Bradler, S. Phylogeny of the stick and leaf insects (Insecta: Phasmatodea). Species Phylogeny Evol. 2009, 2, 3-139.

118. Bradler, S.; Cliquennois, N.; Buckley, T.R. Single origin of the Mascarene stick insects: Ancient radiation on sunken islands? BMC Ecol. Evol. 2015, 15, 196. [CrossRef] [PubMed]

119. Klante, H. Die Wandelnden Blätter-Eine taxonomische revision der Gattung Phyllium Ill. (Insecta Orthoptera, Phasmatoptera). Zool. Beiträge 1976, 22, 49-79.

120. Büscher, T.H.; Buckley, T.R.; Grohmann, C.; Gorb, S.N.; Bradler, S. The Evolution of Tarsal Adhesive Microstructures in Stick and Leaf Insects (Phasmatodea). Front. Ecol. Evol. 2018, 6, 69. [CrossRef] 
121. Forni, G.; Martelossi, J.; Valero, P.; Hennemann, F.H.; Conle, O.; Luchetti, A.; Mantovani, B. Macroevolutionary analyses provide new evidences of phasmids wings evolution as a reversible process. BioRxiv 2020, 10.14.336354. [CrossRef]

122. Buckley, T.R.; Attanayake, D.; Nylander, J.A.A.; Bradler, S. The phylogenetic placement and biogeographical origins of the New Zealand stick insects (Phasmatodea). Syst. Entomol. 2010, 35, 207-225. [CrossRef] 